\title{
European Wool Carder Bee, Anthidium manicatum (Linnaeus) (Insecta: Hymenoptera: Megachilidae) ${ }^{1}$
}

\author{
Samantha Gallagher and Andrea Lucky²
}

\section{Introduction}

The European wool carder bee Anthidium manicatum (Linnaeus) is a solitary, cavity-nesting bee species in the family Megachilidae (tribe Anthidiini), a family whose members include the mason and leaf cutter bees. Wool carder bees are so named because the female bee scrapes and collects the soft downy hairs (trichomes) of fuzzy plants to use in building a nest for her young. Some consider male wool carder bees very charismatic and enjoy watching them chase after other bees that invade their territory, while others would call them bullies based on male bees' aggressive tendencies toward other bees when defending floral resources.

This species has been called the most widely distributed unmanaged bee in the world (Strange et al. 2011) because of its expansive native and non-native range.

\section{Synonymy}

- Apis manicata Linnaeus (1758)

- Apis pervigil Harris (1776)

- Apis maculata Fabricius (1781)

- Apis fulvipes_homonym de Villers (1789)

- Apis modesta Christ (1791)

- Apis amoenita Christ (1791)

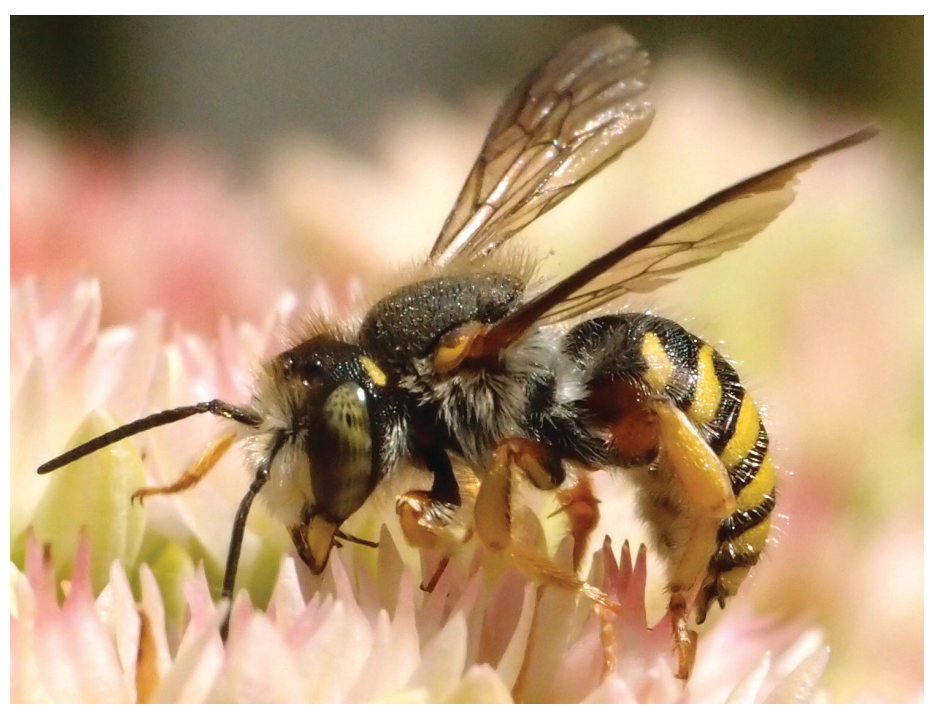

Figure 1. Adult male European wool carder bee, Anthidium manicatum (Linnaeus).

Credits: Samantha Gallagher, UF/IFAS

- Apis uncata Schrank (1802)

- Anthidium maculatum Latreille (1806)

- Anthidium marginatum Latreille (1809)

- Anthidium obtusatum Lepeletier (1841)

- Anthidium barbarum Lepeletier (1841)

- Anthidium productum Lepeletier (1841)

- Anthidium manicatum var nigrithorax Dalla Torre (1877)

- Anthidium manicatum var fasciatum Schirmer (1915)

1. This document is EENY-746, one of a series of the Entomology and Nematology Department, UF/IFAS Extension. Original publication date December 2019. Visit the EDIS website at https://edis.ifas.ufl.edu for the currently supported version of this publication. This document is also available on the Featured Creatures website at http://entomology.ifas.ufl.edu/creatures.

2. Samantha Gallagher; and Andrea Lucky; Entomology and Nematology Department, UF/IFAS Extension, Gainesville, FL 32611.

The Institute of Food and Agricultural Sciences (IFAS) is an Equal Opportunity Institution authorized to provide research, educational information and other services

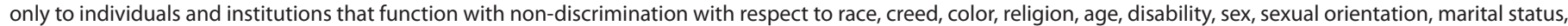

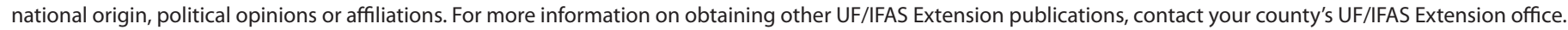
U.S. Department of Agriculture, UF/IFAS Extension Service, University of Florida, IFAS, Florida A \& M University Cooperative Extension Program, and Boards of County Commissioners Cooperating. Nick T. Place, dean for UF/IFAS Extension. 
- Anthidium manicatum var nasicolle Friese (1917)

- Anthidium manicatum var luteus_homonym Gribodo (1924)

- Anthidium manicatum subcrenulata Alfken (1931)

- Anthidium (Anthidium) manicatum cyrenaica_homonym van der Zanden (1992)

- Anthidium (Anthidium) manicatum gribodoi Schwarz and Gusenleitner, 2003, replacement name

- Anthidium (Anthidium) manicatum gribodoi Schwarz and Gusenleitner, 2003, valid subspecies

- Anthidium (Anthidium) manicatum barbarum Lepeletier (1841), valid subspecies (Discover Life 2019)

\section{Distribution}

Anthidium manicatum is native to Europe, western Asia, and northern Africa, but has expanded its range around the globe. It was accidentally introduced into the United States and first recorded near Ithaca, New York, in 1963 (Pechuman 1967), and eventually expanded its range to Nova Scotia and parts of Utah (Gibbs and Sheffield 2009). It is likely the bee has been transported via nests in wood cavities and hollow plant stems (Strange et al. 2011). Current records indicate that the bee can be found in most of South America, especially along the east coasts of Brazil and Uruguay, across Asia and into Siberia and throughout New Zealand, and across most of the United States and into southern Canada (Gibbs and Sheffield 2009). As of this publication, no records of the bee have been reported in Florida (Discover Life 2019), but given its broad distribution, its eventual presence in Florida would not be surprising.

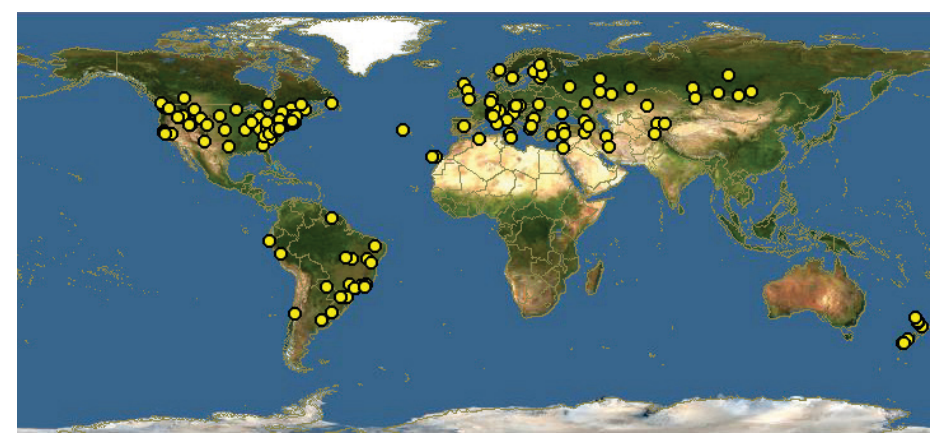

Figure 2. Global distribution of Anthidium manicatum (Linnaeus). Credits: Discover Life, https://www.discoverlife.org/20/ q? search=Anthidium+manicatum, September 8, 2019.

\section{Description}

Wool carder bees are somewhat large bees, 11 to $17 \mathrm{~mm}$ ( $7 / 16$ to $5 / 8$ inch), approximately the size of a honey bee. At a glance, wool carder bees could be mistaken for yellow jackets (Figure 1) since both display aposematic, bright yellow markings, but wool carder bees are hairier and more robust in shape than yellow jackets.

Male Anthidium manicatum (Figure 3) range from 14 to 17 $\mathrm{mm}(1 / 2$ to $5 / 8$ inch) and usually have more yellow on their bodies than do females, although color patterns can vary greatly. Males have light colored setae (hair-like structures) on their body and face and long setae on their legs. They have five sharp spines on the last segments of their abdomen. The spines are used while defending their territory from other bees (Gonzales and Griswold 2012).

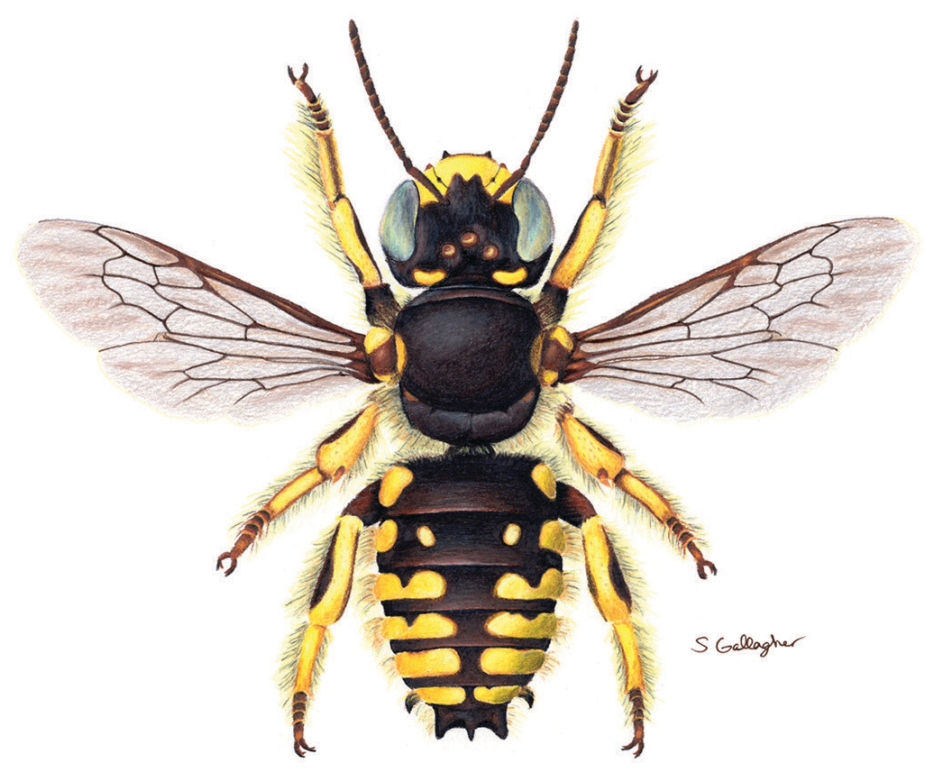

Figure 3. Male Anthidium manicatum (Linnaeus).

Credits: Samantha Gallagher, UF/IFAS

Female Anthidium manicatum (Figure 4) are smaller than males and are 11 to $13 \mathrm{~mm}$ ( $7 / 16$ to $1 / 2$ inch) in length. This is very unusual among bees as females are typically the larger sex. Females have large mandibles with sharp teeth used for collecting and manipulating plant trichomes (hairs) for their brood nests. They have short, dense, compact setae on their lower legs (the basitarsi) which help to organize the collected plant fibers into a ball. On the underside of their abdomens, they have white-to-amber colored hairs (scopa) used for collecting pollen (Gonzales and Griswold 2012). 


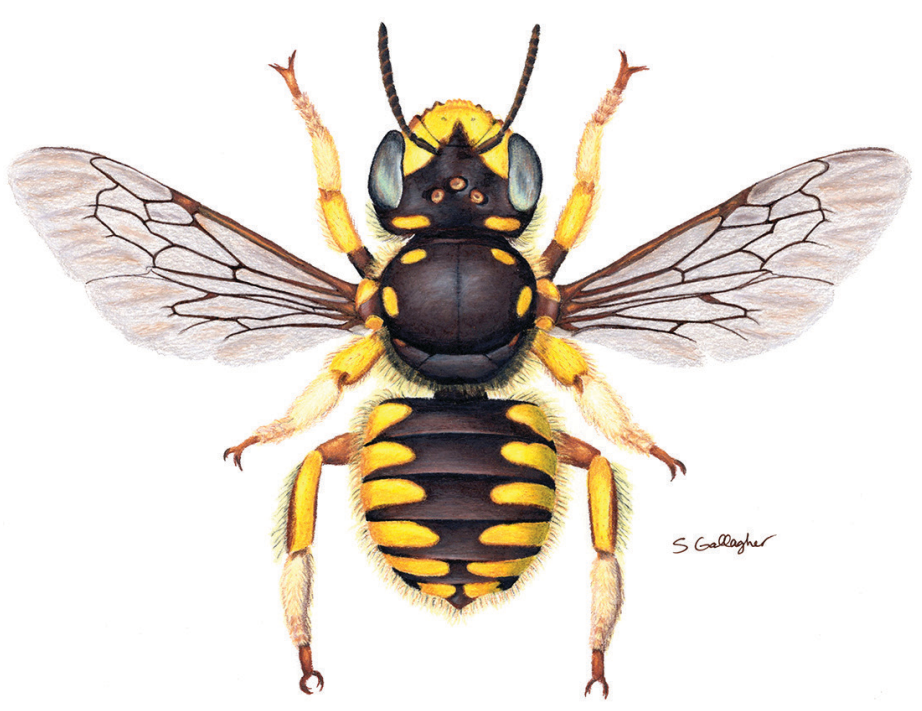

Figure 4. Female Anthidium manicatum (Linnaeus).

Credits: Samantha Gallagher, UF/IFAS

\section{Life Cycle and Biology}

Anthidium manicatum are holometabolous insects and undergo complete metamorphosis. Wool carder bees are solitary bees. Each individual solitary female will find a nest site, lay eggs, collect food for the young, and construct all parts of the nest. Females use existing cavities for brood cell construction. Potential nest sites include cavities in wood such as those excavated by beetles or other insects, hollow plant stems and reeds, crevices and cracks in walls, and man-made bee houses (Figure 5) (Payne et al. 2011).

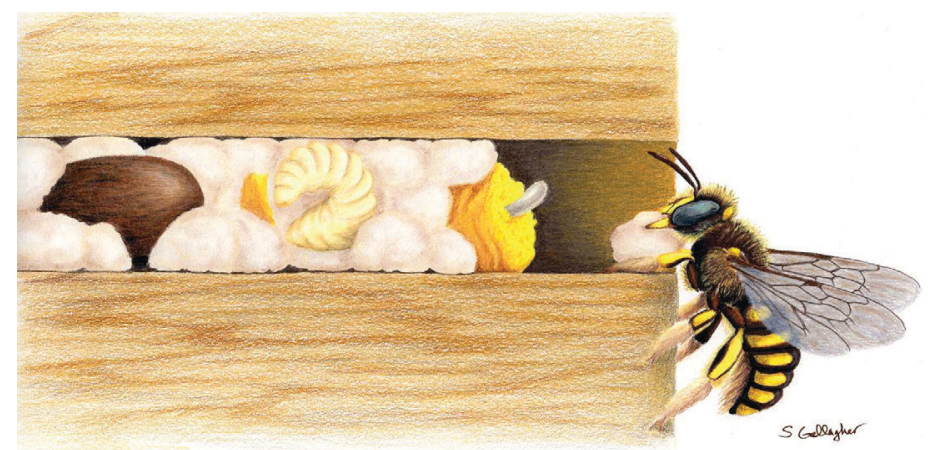

Figure 5. Rendition of life stages (in order from left to right: pupa, larva, egg, and adult female) inside of a cavity nest of Anthidium manicatum (Linnaeus). Note the pollen collecting hairs on the underside of the adult bee's abdomen.

Credits: Samantha Gallagher, UF/IFAS

The female uses her toothed mandibles to scrape trichomes off fuzzy plants and collects a ball of the material under her abdomen (Figure 6). She transports these soft plant fibers to her selected nest site and uses them to line a brood cell. Next, she collects and deposits a provision of pollen and nectar into the cell, enough pollen to feed a larva until it is ready to pupate. Lastly, she lays a single egg on top of the pollen and nectar supply before sealing the cell. The terminal plug is made from nearby particulate material including gravel, mulch, and bits of dried leaves (Payne et al. 2011). She will repeat this process with adjoining cells until the cavity is full (Payne et al. 2011).

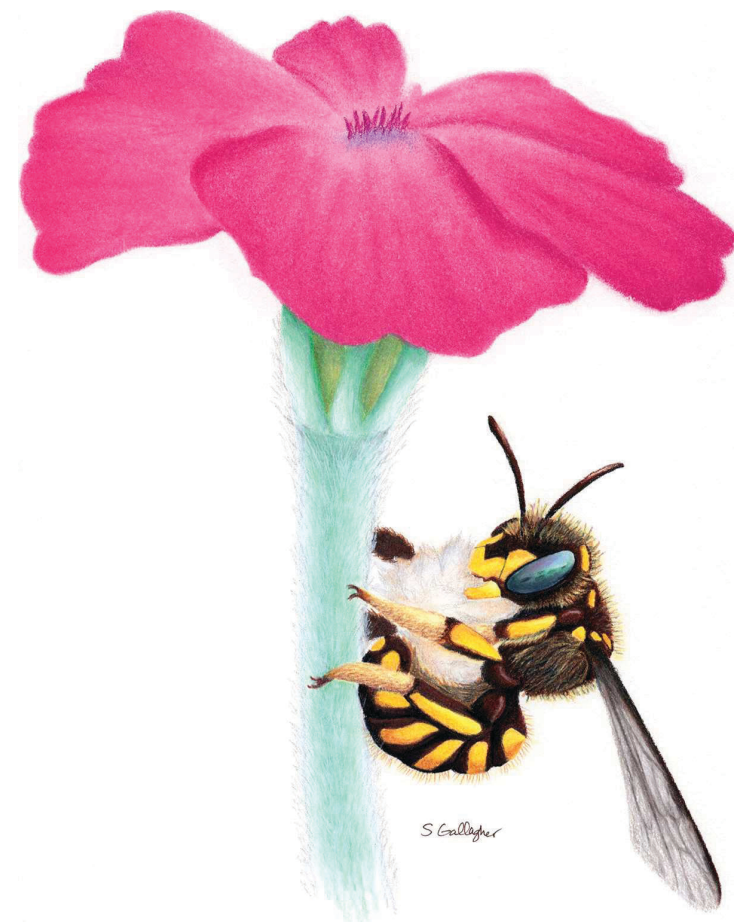

Figure 6. Female Anthidium manicatum (Linnaeus) gathering fibers from rose campion (Silene coronaria).

Credits: Samantha Gallagher, UF/IFAS

A larva emerges from its egg and consumes the pollen provision while remaining in the nest cell. The larva grows, develops, pupates within the cell, and emerges from the nest as an adult. In most areas there are at least two generations a year (Severinghaus et al. 1981). Eggs laid in the fall will overwinter as prepupae and emerge as adults the following spring or early summer (Payne et al. 2011).

Male wool carder bees are notorious for their aggressive behavior defending floral resources for the females. A male will perch or hover near the preferred flowers of the female bees and act as a guard when other bees (including other male wool carders) invade his territory, quickly advancing on and thwarting any offending intruders. The purpose of this intense flower guarding is to provide females with sole access to resources in the male's territory so that he can attempt to mate with the females (Pechuman 1967).

\section{Hosts}

Anthidium manicatum females use trichomes derived mostly from European and Asian plants for their nests (Gibbs and Sheffield 2009). The most common plants utilized by female Anthidium manicatum for nesting material have abundant trichomes, like lamb's ears (Stachys byzantina) and other plants in the mint (Lamiaceae) family 
(Hicks 2011). Other plants from which these bees harvest nesting material include rose campion (Silene coronaria) (Figure 6) and mulleins (Verbascum sp.). The plants are not thought to be damaged by this fiber harvesting.

Anthidium manicatum are generalist feeders, taking nectar from a variety of different plants (Figure 7). The most reported flowers visited by the bees for foraging are dead nettles, Stachys spp., various other mints (Lamiaceae family), peas and legumes (Fabaceae family), and figworts (Scrophulariaceae family) (Hicks 2011).

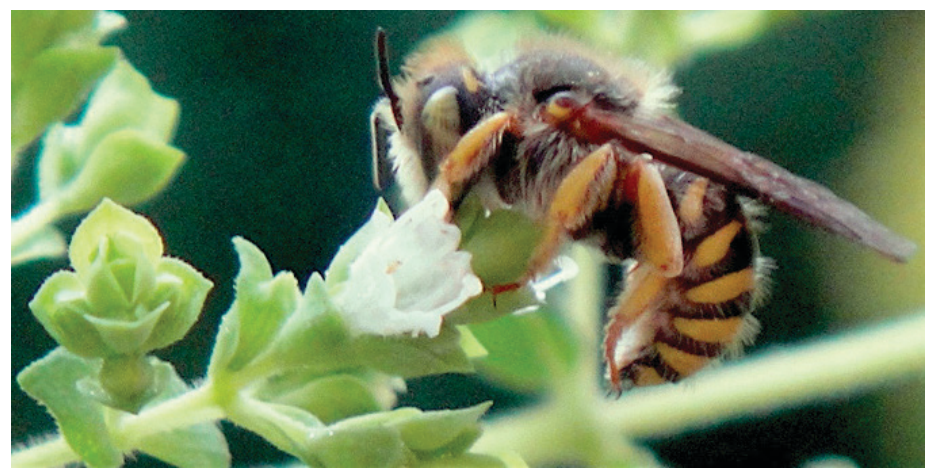

Figure 7. Female Anthidium manicatum (Linnaeus) visits oregano (Origanum vulgare).

Credits: Samantha Gallagher, UF/IFAS

\section{Economic Importance}

Anthidium manicatum have proven to be very adaptable to a wide range of climates and habitats. Globally, the introduction and spread of non-native species exacerbates a loss in native species and threatens biodiversity (Gibbs and Sheffield 2009). Currently, Anthidium manicatum seem most populous in urban environments, which tend to offer more introduced plants than do natural areas (Gibbs and Sheffield 2009). Non-native bees often prefer non-native flowers, and when these are pollinated, there may be increased risk of the non-native plants spreading into and disrupting delicate ecosystems. As with any non-native bee species, there is concern of introducing pathogens that could infect native bees (Gibbs and Sheffield 2009).

The expanding range of Anthidium manicatum raises concerns of competition with native bees for critical resources such as nesting sites, pollen, and nectar (Gibbs and Sheffield 2009). Male Anthidium manicatum can be quite aggressive to other bees when defending floral territory, there has been some concern that they are killing honey (and other) bees (Pechuman 1967). Comba et al. (1999) observed declines in bumblebee visits to certain flowers when Anthidium manicatum males were present, so the impact of Anthidium manicatum in areas with sensitive bumblebee populations is something that should be surveyed and monitored (Gibbs and Sheffield 2009).

\section{Selected References}

Comba L, Corbet S. A., Hunt L., and Warren B. 1999.

"Flowers, nectar and insect visits: Evaluating British plant species for pollinator-friendly gardens." Annals of Botany 83: 369-383. https://doi.org/10.1006/anbo.1998.0835

Discover Life. (2019). “Anthidium manicatum (Linnaeus 1758).” Discover Life. www.discoverlife.org/mp/20q? search $=$ Anthidium + manicatum (September 2019).

Gibbs J., and Sheffield C. S. 2009. "Rapid range expansion of the wool-carder Bee, Anthidium manicatum (Linnaeus) (Hymenoptera: Megachilidae), in North America." Journal of the Kansas Entomological Society 82(1): 21-29. https:// doi.org/10.2317/JKES805.27.1

Gonzales V. H., and Griswold T. L. 2012. "Wool carder bees of the genus Anthidium in the Western Hemisphere (Hymenoptera: Megachilidae): diversity, host plant associations, phylogeny, and biogeography." Zoological Journal of the Linnean Society 168: 221-425. https://doi.org/10.1111/ zoj.12017

Hicks B. 2011. "Anthidium manicatum (L.) (Hymenoptera: Megachilidae) found on the island of Newfoundland, Canada." Journal of the Acadian Entomological Society 7: 105-107.

Payne A., Schildroth D., and Starks P. 2011. "Nest site selection in the European wool-carder bee, Anthidium manicatum, with methods for an emerging model species." Apidologie 42(2): 181-191. https://doi.org/10.1051/ apido/2010050

Pechuman L. L. 1967. "Observations of the behavior of the bee Anthidium Manicatum (L.)." Journal of the New York Entomological Society 75(2): 68-73.

Severinghaus L. L., Kurtak B. H., and Eickwort G. C. 1981. "The reproductive behavior of Anthidium manicatum (Hymenoptera: Megachilidae) and the significance of size for territorial males." Behavioral Ecology and Sociobiology 9: 51-58. https://doi.org/10.1007/BF00299853

Strange J. P., Koch J. B., Gonzalez V. H., Nemelka L., and Griswold T. 2011. "Global invasion by Anthidium manicatum (Linnaeus) (Hymenoptera: Megachilidae): Assessing potential distribution in North America and beyond." Biological Invasions 13: 2115-2133. https://doi.org/10.1007/ s10530-011-0030-y 